\title{
Arrival in Shanghai: A Sanctuary for Jewish Refugees (1933-1941)
}

\author{
Weihan Liu \\ La Salle High School, Pasadena, CA, USA \\ Email: whliu727@gmail.com
}

How to cite this paper: Liu, W. H. (2021). Arrival in Shanghai: A Sanctuary for Jewish Refugees (1933-1941). Sociology Mind, 11, 25-31.

https://doi.org/10.4236/sm.2021.111003

Received: December 9, 2020

Accepted: January 17, 2021

Published: January 20, 2021

Copyright (c) 2021 by author(s) and Scientific Research Publishing Inc. This work is licensed under the Creative Commons Attribution International License (CC BY 4.0).

http://creativecommons.org/licenses/by/4.0/

\begin{abstract}
Between 1933 and 1941, approximately 30,000 Jewish refugees arrived on the coast of Shanghai. While some of them passed through to other countries for sanctuary, most of them stayed in Shanghai until the war ended. These refugees represented the Third Wave of Jewish migration into Shanghai. In the light of the Sino-Japanese war, the governing authorities in Shanghai tried to stem the influx of Jewish refugees. Despite this pressure, the Jewish refugees managed to not only enter Shanghai but quickly create thriving communities in the Tilanqiao area. This paper argues that they were able to do this because of extensive help provided by already established Jewish communities in Shanghai and overseas organizations such as the Joint Distribution Committee. The support provided by these entities is often underplayed in the official historical reports of this time. Using documentary evidence and refugee memoirs, this paper will argue that in the absence of this help from the Jewish communities and overseas organizations, the Jewish refugees would not have been able to enter Shanghai, escape Nazi persecution and thrive in the way that they did.
\end{abstract}

\section{Keywords}

Shanghai, Jewish, Refugees, Nazi, Joint Distribution Committee

\section{Introduction}

During World War II, thousands of Jews fled Nazi persecution in Europe to find refuge in countries across the globe including Shanghai. There had been two previous waves of Jewish migration into Shanghai. The first occurred in the $19^{\text {th }}$ century and consisted of traders arriving from the Middle East. The second occurred toward the end of the $19^{\text {th }}$ century, consisting of Jews fleeing Anti-Semitism in Russia. The Jews in the third wave, unlike those in the other two 
waves, came primarily from central Europe-particularly Poland. In the 1930s and 1940s, approximately 30,000 Jews relocated in Shanghai. Of these, 5000 stopped in Shanghai in search of a more permanent refuge; the remaining 25,000 lived in temporary dwellings until the end of World War II. Most of these Jews chose to live in Shanghai's Tilanqiao area. (Eber, 2012)

Shanghai became a popular choice for Jewish refugees for two primary reasons. One is that in light of the economic depression, the looming threat of war and rising Anti-Semitism, most countries had closed their borders to immigrants, particularly Jews. Amidst this hostility, Shanghai stood out as the only metropolitan city in the world that had no restrictions to the entry of foreigners. The second reason is that the Jews faced no persecution in Shanghai. Anti-Semitism never took root in China and even after Shanghai came under Japanese control in 1939, Jews faced none of the persecution that was characteristic of Europe at that time. It is no wonder that Shanghai rapidly became a popular choice for destitute Jews. (Guang, 2002)

However, this does not mean that the Jews in the Third Wave encountered no opposition in Shanghai. As the refugees scrambled to create a home for themselves, they faced stiff resistance from the governing foreign authorities who put pressure on the local Jewish communities to stem the further influx of refugees. Among these governing authorities were the French, the British, the Japanese, and the Shanghai Municipal Council (SMC).

The SMC was an administrative body consisting of British, American, Chinese, and Japanese officials. The SMC's power in Shanghai was shaped in the wake of the Opium War of 1842. (Altman \& Eber, 2000) At that point, the two largest districts of Luan and Xuhui, became the International Concessions (I.C.) governed by the Shanghai Municipal Council. The SMC derived its power primarily from British authorities. When the Chinese Nanjing Republican government was floundering both at home and abroad-due to both domestic political conflict and international military failures-these foreign bodies assumed control and divided a large part of Shanghai into the International Concession and the French Concession, each with its own administration.

Tensions with Japan reached a peak with the start of the Second Sino-Japanese War in 1937. In a short period of time, Japanese forces took over large parts of Chinese-controlled Shanghai. Shipping came to a halt and the Shanghai ports were closed. The Japanese slowly assumed considerable control over Chinese business and media. To compound this, the municipal government in Shanghai was struggling with the government in Nanjing for control over Shanghai. It was in this tense atmosphere of mounting apprehension that the Third Wave of Jewish refugees arrived on the coast of Shanghai. The foreign community, especially the British were already strained by the situations in Shanghai and did not take well to these new, unexpected guests.

The fighting in 1937 had left Shanghai weak and low on resources, unable to cope with the influx of Jewish refugees. They were unable to provide them with adequate housing and employment opportunities. As a result, the governing au- 
thorities in Shanghai-British, French, and Japanese-tried to restrict the flow of Jewish refugees into Shanghai. However, the lack of passport controls in Shanghai coupled with the desperate plight of the Jews, made these restrictions almost impossible.

The refugees had fled dire conditions in Nazi occupied parts of Europe, leaving behind friends, families and homes to make a treacherous journey across the ocean and arrive in a completely foreign country. Their situation was made worse by the hostility of the SMC who were opposed to the unrestricted influx of Jewish refugees. The estranged Jews would not have survived their destitute situation were it not for the assistance of the already-established Jewish communities and overseas organizations.

This paper will examine the relationship between the refugees of the third wave, the Jewish community in Shanghai, and other organizations that played a role in the migration. Following this initial examination, the paper will introduce primary sources to demonstrate that although the Jews faced challenges during their flight to Shanghai, they were met with support both from local Jewish communities and allies overseas which was crucial for their survival. This support has often been underplayed by scholars of this topic. The main reason for this is that until the 1990s, scholars did not have access to the archival stories of the third wave of Jewish migration to Shanghai. This is mainly because the Jews who escaped to Shanghai did not tell their stories publicly since they believed that the public narrative should rightly be given over to the Jews who had managed to survive the horror of the Holocaust. Many Jews who escaped to Shanghai, "were reluctant to place their experiences next to those who had barely escaped death in Europe." (Hochstadt, 2012) It took almost 40 years for the stories of Jewish refugees to become known to scholars, finally challenging the mainstream view that these refugees were not helped by wealthy communities in Shanghai and abroad.

A fair evaluation of the support provided by these entities is necessary to understand how it was possible for the Jewish refugees to not just survive but thrive in Shanghai. Without this perspective, our picture of the Third Wave of Jewish migration remains thoroughly incomplete. This paper will fill in these gaps by evaluating information collected through first-person accounts of the life of Jewish refugees in Europe that came to light only in the 1990s. The paper will additionally reflect on why the absence of these accounts had led to the neglect of an important aspect of the Third Wave of Jewish migration to Shanghai-the support provided by Chinese, Jewish and overseas communities. In this way, the paper hopes to clarify past misconceptions based on insufficient knowledge and thereby contribute to the history of Jewish refugees in Shanghai.

\section{Historical Background of First Two Waves}

The Treaty of Nanjing (1842) which marked the end of the Opium War (Waley, 2013), brought to a close 100 years of self-seclusion and the rise of international 
trade with China. Shanghai was quick to become a thriving port, attracting businessmen from all over the world. Sephardic Jews from Baghdad, Bombay, Singapore, and Hong Kong were the first to arrive in Shanghai for business.

During the days following the treaty, Shanghai was an ideal destination for long-distance trade because of its well-developed port system. Jews who began by dealing in opium, tea, and silks quickly shifted to real estate, oil, manufacturing, and finance. Some Jewish trading families such as the Sassoons, the Hardoons, and the Kadoorie soon became some of the wealthiest people in Shanghai.

After the rise of anti-Semitism in the Russian Empire during the late 19th century followed by civil war in the early 20th century, a second wave of Jewish migrants fled to Shanghai. These Jews, unlike the earlier wave of immigrants, were of Ashkenazi (European) origin and were seeking asylum, not engaging in trade. (Eber, 2012) Compared to the earlier wave of wealthy merchant families, these refugees were poorer and larger in number. By the 1930s, there were about 4000 Russian Jews settled in the intersection of the Huangpu River and the Suzhou River, now called the Tilanqiao Area. Running grocery stores, tailor shops, and clinics, they succeeded economically and created a middle-class community. (Eber, 2008)

\section{Relationship between the Third Wave and Its Predecessors}

In her article Wartime Shanghai, (Eber, 2012) Irene Eber argues that the Jews of the third wave from Central Europe were not welcomed by the local non-Jewish authorities, including the SMC, French, British, and Japanese. The governing authorities in Shanghai did not want to appear Anti-Semitic and be seen turning away Jews but at the same time, they were unable to provide for the refugees. As a result, the SMC started to put considerable pressure on the wealthy Jewish businessmen, asking them to take responsibility for the fellow members of their religion. Concerned about their standing vis-a-vis the British, wealthy Jewish families who would not otherwise have provided help were pressured to do so. However, some Jewish trading families like the Sassoons were actively helping the Third-Wave Jewish refugees, even in the absence of pressure from the authorities.

The memoirs of refugees from Steve Hochstadt's Exodus to Shanghai, (Hochstadt, 2012) display the importance played by these wealthy Jewish communities in accepting new Jewish refugees and supporting those who had already taken refuge in Shanghai. "Without material resources, political rights, or physical safety, but with the crucial financial help of Jews around the world, including Baghdadi and Russian Jews in Shanghai, the refugees built a society of survival ..." (Hochstadt, 2012)

In fact, the Baghdadi Jewish community-headed by Paul Komer, the Honorary Consul general for Hungary-even created a relief committee formed to 
"greet the refugees, provide temporary housing, and integrate them into the Shanghai economy. The Sassoon and Kadoorie families used their wealth and influence to smooth the descent of these Europeans into refugee status ..." (Hochstadt, 2012)

From these sources, we can see that the existing Jewish communities were instrumental in taking charge of the lives of the incoming Jewish refugees and ensuring that they could assimilate into a new way of living in Shanghai. Without this support, the Jewish refugees would likely have been driven away by the SMC due to lack of adequate support and resources.

\section{Expanding the Material and the Dramatis Personae}

The official narrative of the Third Wave Jewish migration neglects the role played by certain players in the local Jewish and international communities. Documentary materials can help expand the scope of the discussion about the refugee migration by shedding light on the relationship between the refugees and the Sassoon family, Paul Komer and He Fengshan-the Consul General of China in Austria.

The relief activities were carried out through two major projects: 1) the mobilization and management of funds and 2) the establishment of enterprises serving Jewish refugees. The Sassoons played a key role in fund-raising and management of funds. The Sassoons donated $\$ 150,000$ in recovery funds to the I.C. to restore war-torn businesses, providing new jobs for Jews. By the end of 1939, there were more than 3300 Jewish refugees, who were financially independent from the loan fund. By the end of 1941, the recovery fund amount had increased to $\$ 238,000$. (Guang, 2019) Additionally, to address the housing problem, the Sassoon family donated part of the Embarkment Building to the I.C along with other smaller housing options. The Embarkment building was the largest apartment building in Shanghai, covering an area of about 7000 square meters which provided housing to thousands of estranged refugees.

In short, many Jewish refugees were able to sustain their lives with funds raised by the I.C., but these funds could not last forever. The refugees needed to become self-sufficient. Paul Komer stepped in and issued ID cards to Jews, helping them find jobs in this foreign economy. Groups to aid the assimilation of Jewish refugees were established. Among these were the Jewish Migration Assistance Association, the Committee For the Assistance to Eastern European Refugees, and the American Jewish Joint Distribution Committee. The last of these was founded in the United States in 1914 by merging three other relief organizations. After 1941, the organization established a Far East Office and quickly became one of the largest relief organizations in Shanghai. These organizations helped the Jewish people receive the support they needed to stand on their own two feet and create a life in Shanghai.

Austria's Consul general, He Fengshan, played a crucial role in this as well. To adequately understand his role, Fengshan's experience during the Evian Confe- 
rence must be examined. The Evian conference was held on July 13, 1938 to discuss the issue of the Jewish refugees. Many of the thirty-two countries participating in the conference were able to provide funds for refugees, but against the backdrop of global turmoil, they could not provide visas to a large number of Jews fleeing Central Europe. Shanghai, thus, became a leading destination for many of these Jews.

Between 1937 and 1940, Fengshan issued thousands of visas to Jews in Central Europe, although it is difficult to ascertain the precise number. Due to the lack of proper passport controls, Shanghai became the only city in China to receive Jews at that time. There were around 30,000 Jewish refugees in Shanghai at its peak, more than those in Canada, Australia, India, South Africa, and New Zealand combined.

He Fengshan's story is not mentioned in Irene Eber and Steve Hochstadt's books. It is speculated that there are two reasons for this. First, when Shanghai was occupied by Japan, foreigners could enter the city without visas. Therefore, scholars may not acknowledge the value of He Fengshan's efforts to provide visas. Second, after the end of World War II, China fell into a civil war. In the face of these turbulent political conditions, He Fengshan's achievements were not properly recognized. Although visas were not required to enter Shanghai, Jews could not leave Austria without one to relocate.

The contributions from the Sassoon family, Paul Komer, He Fengshan and other relief organization help us understand the extent of the support provided to the Jewish refugees and expands our understanding of their situation.

\section{Conclusion}

Shanghai's reception of the influx of Jewish refugees was complex and multi-dimensional. While the British, SMC, and French fought adamantly to limit refugees from coming to Shanghai, the Jews received benevolent support from He Fengshan, Paul Komer, and the existing Jewish communities. With this support, the refugees began their new lives in an unfamiliar city. Although their stay in Shanghai was short and temporary, these experiences reflect the resilience that Jewish history often exhibits. By introducing new documentary materials, this paper has attempted to expand and clarify the official understanding of the Third Wave of Jewish migration to Shanghai.

\section{Conflicts of Interest}

The authors declare no conflicts of interest regarding the publication of this paper.

\section{References}

Altman, A., \& Eber, I. (2000). Flight to Shanghai, 1938-1940. The Larger Setting (pp. 51-86). Shoah Resource Center.

Eber, I. (2008). Voices from Shanghai: Jewish Exiles in Wartime China. Chicago, IL: University of Chicago Press. 
https://doi.org/10.7208/chicago/9780226181684.001.0001

Eber, I. (2012). Wartime Shanghai and the Jewish Refugees from Central Europe. Berlin: De Gruyter.

Guang, P. (2002). Shanghai: A Haven for Holocaust Victims.

Guang, P. (2019). Jewish Refugees Arriving in China (1933-1941): Route, Time, Number and Resettlement. In P. Guang (Ed), A Study of Jewish Refugees in China (1933-1945) (pp. 11-28). Berlin: Springer. https://doi.org/10.1007/978-981-13-9483-6 2

Hochstadt, S. (2012). Exodus to Shanghai. London: Palgrave Macmillan US.

Waley, A. (2013). The Opium War Through Chinese Eyes. Abingdon-on-Thames: Routledge. 